FACTA UNIVERSITATIS

Series: Law and Politics Vol. 15, No 3, 2017, pp. 211 - 221

https://doi.org/10.22190/FULP1703211A

Review Article

\title{
NEONATICIDE
}

\author{
UDC 343.622
}

\section{Iva Antić}

Faculty of Law, University of Niš, Republic of Serbia

\begin{abstract}
Murder is undoubtedly the most difficult and most far-reaching consequence of criminal activity which deserves considerable attention of professional and general public alike. As a rule, the role of killers is usually attributed to men while women are more frequently seen as victims, which does not fully correspond to social reality. In that context, the subject matter of this paper is neonaticide, as a type of homicide typically committed by women. The author examines the historical, criminal and criminological aspects of this crime in an endeavour to determine a typical profile of a woman who kills her newborn child. The research results confirm the terrifying facts that the criminal act of neonaticide may be committed by any woman, whereby some women prove to be more prone to killing their children than others. For this reason, the author explores the distinctive characteristics of women who commit neonaticide, which distinguish them from other women-murderers. The ultimate goal of this paper is to draw attention of primarily professional public to this interesting and insufficiently researched topic and to emphasize the need for its more comprehensive examination in the future.
\end{abstract}

Key words: neonaticide, woman, murder, murderer
"Whoever is found to have killed his father, or mother, or brother, or his own child, is to be burnt alive."

Dushan's Code (Article 94), 1349

\section{INTRODUCTION}

As one of the most heinous criminal offences, neonaticide has always been a controversial issue that inevitably captures the attention of the immediate environment where the crime was committed, the professional public and the general public alike, bringing forth obscene

Received February 22 $2^{\text {nd }}, 2017$ / Accepted June 26 $6^{\text {th }}, 2017$

Corresponding author: Iva Antić, LL.M, PhD Student

Faculty of Law, University of Niš, Trg Kralja Aleksandra 11, 18000 Niš, Republic of Serbia

E-mail: ivaantic91@gmail.com 
amounts of disapproval and indignation. There is no unique stance on this gripping matter, which makes the topic even more intriguing and suitable for discussion involving different types of experts (legal practitioners, psychologists, psychiatrists, gynecologists, etc.) as well as laymen. In addition to being viewed as a negative and highly unacceptable social phenomenon, neonaticide is invariably considered to be a highly unnatural criminal act, i.e. a criminal offence against the laws of nature. Besides being considered a violation of the sanctity of innocent human life of the newborn baby, this crime constitutes a negation of the natural, inherent and healthy mother-child relationship essentially featuring mother's love and affection for the newborn. Neonaticide implies annihilation of the strong intrinsic bond which exists, or should exist, in mother's relations towards the newborn.

Although the origin of this crime may be traced back to the ancient times, the question which inevitably arises and has been posed ever since is what kind of circumstances make a woman harm her own child and act against nature and her inborn maternal instincts. It gives rise to a number of other questions. What kind of political, psychological, social and sexual implications are associated with this criminal act? What is the role of the immediate social environment when it comes to extramarital motherhood, and to what extent it affects the mother's commission of neonaticide? How does the community perceive single mothers? What is the mother's financial standing (in terms of regular sources of income, housing, employment, etc.)? Does she have the capacity to consider some alternative course of action, other than neonaticide? Furthermore, what are the distinctive personality traits that distinguish such mothers (baby-killers) from other women? Why are they given a more privileged position when compared to other women-murderers? And above all, does the existing theoretical argumentation provide sufficient justification for the privileged treatment of perpetrators of neonaticide in many criminal law systems as well as in Serbian law?

In response to the question concerning what drives a mother to murder her own child or to let it die, Schwartz and Isser (Schwartz, Isser, 2012: 45) came to the conclusion that this single question involves quite a number of multifaceted issues: Does the woman accept or refuse to accept the fact of pregnancy? What is the nature of her relations with her own parents? What is the role of religion in this matter, and the impact of religious beliefs she has been exposed to? What is the legislator's attitude to abortion reflected in the legislation on neonaticide? Finally, is neonaticide a belated alternative for abortion or, is abortion (as claimed by many) neonaticide in its early stage? (Antić, 2016: 25).

\section{THE HISTORY OF NEONATICIDE}

Historically speaking, even though neonaticide had been regarded as one of the most heinous criminal acts in ancient days, the treatment of this crime has significantly changed in modern times. Today, it has the status of a privileged criminal act in the majority of criminal legislations, including the legislation of the Republic of Serbia.

The first traces of a criminal act akin to this one can be found in the Bible, with reference to Abraham who killed his son Isaak. Derived from Greek mythology, the Medea's complex refers to the story where Medea murders two of her sons, thus taking revenge on her husband who had abandoned her for the daughter of King of Corinth. In Ancient Greece and Rome, neonaticide was explicitly envisaged in the legislation, which prescribed the killing of newborn children when the babies born were found to be weak or deformed, either for eugenic reasons or due to the fact they were considered a burden for the state (Craig, 2004). In 
1981, Japanese authors described two forms of neonaticide typical for the Japanese society: Mabiki - the phenomenon matching "premeditated murder" or population control, and "Anomia"- the "unwanted child syndrome", the phenomenon which is also pertinent to the modern society (Kecman, Kovačević, 2005). In ancient Carthage (Cartagena), there were documented cases of religious rites of sacrificing children to gods and supernatural forces, including the sacrifice to the idol Moloh; it was a statue inside which a fire was lit, while the parents would slaughter their children on the statue's hands, considering this the ultimate sacrifice to the demon (Ilić, 2016: 133).

Until the $18^{\text {th }}$ century, neonaticide was deemed to be one of the most heinous crimes, which was punishable by the most severe forms of punishment: burying the mother alive, impalement, blinding and gruesome torture with hot pliers. The woman who committed this crime was generally deemed to be a monster and "unnatural" being. While in many other criminal offences there is a likelihood of assigning a degree of contributory liability for the committed crime to the victim, it is absolutely impossible in case of neonaticide simply because there is no justification for spilling a child's blood, nor is the child capable of resisting in any way (Konstantinović-Vilić, $1986: 50$ ).

The milder punishments for neonaticide prevailed due to a rising silent awareness of the general public that men are equally responsible for women's pregnancy and, even more so, due to the inability of the society as a whole and the state in particular to accept the child born out of wedlock and re-integrate the mother into the society.

Given the fact that some legislations used to make a distinction between marital and extramarital children, the homicide of a marital child was qualified as an aggravated murder (first-degree murder), which is still the case in Serbian legislation for both marital and extramarital children, while the homicide of extramarital children was qualified as a privileged homicide (manslaughter). This was, for example, the case in former criminal legislation of Germany, which encountered particular difficulties in proving the child's marital or extramarital status. Although this anachronism has been overcome and is no longer part of contemporary legislation, it still embodied a certain discriminatory attitude toward extramarital children.

As previously stated, according to Serbian legislation, neonaticide is one of the four types of privileged homicide envisaged in the Serbian Criminal Code, even though is still a highly disputed topic among the legal theorists. In practice, the number of committed and attempted criminal acts of neonaticide seems to be declining (Antić, 2016: 64).

However, the issue of women's neonaticide is still present in China, North Korea, India and Pakistan, where there is significant traditional preference for male offspring. In order to resolve its demographic issues, China instituted the one-child policy, allowing parents to have only one child; resorting to selective abortion, parents commonly preferred to have boys, given the fact that girls do not inherit the family name, property, and do not have military predispositions ${ }^{1}$. In the most literate Indian state Kerala, the number of murdered female newborns is approximately 25,000 per year while midwives in the state of Bihar in the east of India admit to receiving money to murder at least half of female children they deliver (Banerji, 2009). By contrast, in the USA, where $45 \%$ of child murders occur within the first 24 hours after delivery, there are twice as more male victims than female ones ${ }^{2}$.

\footnotetext{
${ }^{1}$ Gendercide Watch, Case Study: Female Infanticide, www.gendercide.org/case_infanticide.htm

${ }^{2}$ Source: https://en.wikipedia.org/wiki/Neonaticide
} 


\section{THE CRIMINAL ASPECT OF NeONATICIDE}

\subsection{The concept and definition of neonaticide}

Infanticide, filicide or neonaticide (stemming from the Latin words: neonates newborn, and occidere-to kill, murder) are synonyms for the criminal act of child-killing (infanticide), incriminated in Article 116 of the Serbian Criminal Code, ${ }^{3}$ which reads:

"A mother who causes the death of her child during or immediately after delivery, while still under the effect of a post-natal (mental) disorder caused by delivery (post-delivery syndrome), shall be punished by a sentence of imprisonment ranging from six months to five years."

This crime is qualified as a privileged homicide, which includes three essential elements of privileged homicide: 1) the victim is a live-born child; 2) the perpetrator is the mother of the newborn child; and 3) the crime was committed during childbirth or immediately after delivery, due to a (mental) disorder caused by the delivery.

The first two constitutive elements of this criminal act (related to the fact that the only possible offender is the mother, and that the child shall be a live-born child) are commonly accepted. However, there are huge disagreements in legal theory on the presence of "disorder" and its duration. From the forensic standpoint, the following conditions must be met for neonaticide to exist (Konstantinović-Vilić, 1986: 59):

1. The murdered fetus has the status of a newborn child (the umbilical cord has not been cut yet) and has not been breastfed; (yet, the latter condition is disputable, as there are a number of cases of neonaticide where the child was killed after being breastfed);

2. The child is live-born;

3. The child was intentionally killed by the mother;

4. The deprivation of life (homicide) occurred after the delivery of the newborn child, within a period of 3 to 5 days on average, or a period of 5 to 7 days at the latest, after the delivery (Konstantinović - Vilić, 1986: 88).

Considering the nature of the committed act, there are two types of neonaticide: active and passive neonaticide. The active neonaticide implies the commission of the criminal act, which most frequently involves suffocation, strangling or hurting the newborn child. The passive neonaticide implies a failure or omission to act, to provide necessary assistance for survival purposes, abandoning the newborn child, etc. Although both forms of neonaticide theoretically exist, research has shown that the percentage of passive neonaticide is negligible. Neonaticide is most frequently committed by suffocation, drowning the child in water, or murdering the child with an axe.

As for the environment where this crime is committed, neonaticide is more frequently committed in rural areas (villages) than in urban areas (cities), particularly considering the fact that the rural environment is much more patriarchal and homogeneous, that women are much more dependent on their husbands and that the population holds traditional moral beliefs. The rural environment is particularly ruthless in cases involving a woman who has given birth to an extramarital child (Konstantinović-Vilić, 1986: 88); she is often misled by the promise of marriage if she gets rid of the "bastard" child. In the era of industrialization, neonaticide is no longer a typical "rural" crime; it has moved to the city, together with seasonal female workers who were often, due to their inexperience, seduced and then left behind. Besides, a city-

\footnotetext{
${ }^{3}$ Article 116 of the Criminal Code ("Official Gazette of RS", no. 85/2005, 88/2005 - corr., 107/2005 - corr.,
} $72 / 2009,111 / 2009,121 / 2012,104 / 2013$ and 108/2014) 
woman has more opportunities to pursue and maintain her financial independence as compared to the village woman, who is typically financially dependent on the owner of the land she is farming.

Women-killers most frequently deprive their children of life indoors (in apartments or abandoned houses), while only a smaller number opted for open grounds (yards, outdoors toilet facilities), or ditched the bodies in a canal or river (Konstantinović-Vilić, 1986: 89). Speaking of the instruments of crime, only $25 \%$ of women use a knife or a gun to commit neonaticide; they are usually bare-handed, suffocating or strangling their children with bare hands.

\subsection{The Victim}

Regarding the victim (the object of attack), it is first necessary to clarify the concept of a newborn child in order to clearly distinguish the act of neonaticide from other criminal acts, such as: illegal abortion (especially in legislations where the pregnant woman may be held criminally liable for such an act), medically induced cases of removing the unborn child for the purpose of protecting the mother's life, and a deliberate aggravated murder of a child. In order to establish whether a criminal act involves neonaticide (a homicide of a child during or after delivery) or a deliberate aggravated murder of a child, we have to determine the exact point in time from which the fetus considered to be a newborn and the exact the exact point in time when the newborn child becomes an infant.

A majority of theorists state that a fetus becomes a newborn from the moment when the mother experiences the first delivery pains, while others believe it is only after a part of a child has left the uterus. In any case, the remaining question is how long the newborn keeps that status after the delivery. There is a common opinion that a newly-delivered baby has the status of a newborn until the moment he/she has been breastfed, from which point he/she is considered to an infant. In forensic medicine, the time that elapsed from the moment of birth to the moment of death of a newborn child is usually determined on the basis of changes on the child's umbilical cord, in the digestive tract and in the bloodstream (Antić, 2016: 27).

The condition that a child shall be live-born implies that a child needs to be born alive, regardless of whether he/she is capable of staying alive. Additionally, it is irrelevant if the child was born with some physical defects (i.e. different anomalies and deformities), and it is ultimately aimed at protecting every child from the moment of childbirth and preventing potential abuse which could be justified by the potential existence of such defects in a child. The right to live must not be dependent on the physical ability to live (Šaljić, 2010:4).

\subsection{The Perpetrator}

In theory there is a general stance stating that criminal conduct is "man-related phenomenon" while the issue of women perpetrators of crime has often been neglected. Her role of a mother and wife was often incompatible with that of a "woman offender" (Ilić, 2016: 132). However, neonaticide is the only criminal act in criminal legislation which may only be perpetrated by a woman, more specifically the mother of the victim; thus, it is a typical representative of female criminality.

In his classic study of neonaticide in 1970, a psychiatrist Phillip Resnik suggested several motives that make women commit this cruel act (Schwartz, Isser, 2012: 58). His conclusions were based on the 37 cases he found in literature in the period from 1751 to 
1968. Although it is not truly a representative sample for such a long time period, his research showed that as many as $83 \%$ of neonaticide cases were motivated by the fact that the child was undesired, primarily given the social stigmatization of the woman due to the child's extramarital status. As Resnik noted, another motive for committing Neonaticide was the mother's denial and inability to deal with pregnancy; she expected that the child would be stillborn or somehow disappear and, when it did not happen, she decided to commit murder. (Antić, $2016: 28$ )

Neonaticide may also be a consequence of accumulated frustration, particularly the ones stemming from childhood and early youth, which surge in a critical moment and suppress the maternal instinct (Ilić, 2016: 138).

The factor of social necessity is almost crucial in neonaticide cases. Social necessity is defined as a specific state which includes a number of factors and motives: bad financial situations, poor education, social hardship, etc.

\subsection{The post-delivery disorder caused by childbirth}

In order to prove the commission of neonaticide, it is essential to establish that the criminal act was committed at a specific time, during or immediately after the delivery, when the mother is susceptible to the post-delivery disorder (syndrome) cause by childbirth.

In their study of 60 women who had murdered one or more of their children in the period from 1979 and 1996, Lewis, Baranoski, Buhanan and Benedeck found that $52 \%$ of these women were treated as incapable of standing trial, and a whopping $65 \%$ of them were acquitted due to insanity (Schwartz, Isser, 2012: 56).

The existence of the "neonaticide syndrome" was also discussed in the case People vs Vernik (1996) where a college student Stephani Vernik was convicted of involuntary manslaughter for strangling her own newborn son. She raised the insanity defence, denying that she had ever been pregnant. Experts testified that she had denied being pregnant during the entire pregnancy and that this type of denial exists in almost all cases of neonaticide; there was also a possibility she was unaware of her pregnancy so that she suffered a shortterm reactive psychosis after the delivery (Schwartz, Isser, 2012: 56).

The starting point here is that the mother was in an extraordinary physical and mental state in the aforesaid periods, due to delivery pains in child labour, and that her judgment was substantially impaired by her psychosomatic imbalance and mental instability (designated as the "neonaticide syndrome" or post-delivery disorder), which it does not include the cases / where common disturbances typically associated with every pregnancy cause or bring to light a pre-existing mental illness (Konstantinović-Vilić, 1986: 60). The post-delivery disorder can be triggered by exogenous factors, such as: the prejudice of the immediate environment (particularly in cases of extramarital pregnancy), or financial difficulties related to ensuring child support, and the like. On the other hand, these exogenous factors give rise to endogenous disorders, which may be present in the course of pregnancy but reach their peak during the delivery, such as: shame and fear of parents, fear that the spouse may discover that the child is not his, shame or denial when the child is a consequence of rape, and the like.

By studying the existing forensic psychiatry literature, it can be concluded that in the regular course of pregnancy psychiatry does not recognize any extraordinary metal state of the child-bearing woman (Konstantinović-Vilić, 1986: 60). Thus, it is essential to point out that the presence of a neonaticide syndrome or post-delivery disorder has to be established (and not assumed) on the merits of each individual case. 


\section{THE CRIMINOLOGICAL ASPECT OF NEONATICIDE}

\subsection{Classification of women murderers}

According to the classification given by an East German criminologist Elfie Kosewähr (Konstantinović-Vilić, 1986: 61), ${ }^{4}$ there are three types of women who commit neonaticide:

1. The first type is a woman who represses and refuses to accept her pregnancy, or denies her pregnancy, all of which can cause the absence of physiological changes and typical pregnancy symptoms: dizziness, morning sickness, notable weight changes, etc. Throughout pregnancy, this type of woman is deceiving herself, hoping for a stillborn child. Thus, in case of giving birth of a live-born child, her reaction is defensive: she either abandons the newborn child or fails to provide necessary care, as a result of which the child dies. In most cases, such conduct is often deeply rooted in the mother's conflicting relations with her immediate surroundings: the resentment of the highly judgmental local community, the fear of being left by the extramarital partner (the child's father), the antagonism of the family members, particularly in cases where the mother is either a juvenile or an adult financially dependent on her parents. Generally, such conduct is pertinent to psychologically immature and mentally unstable women.

2. What characterizes the second type of women who commit neonaticide is long-term planning and considering different options of getting rid of the child. Hence, the commission of neonaticide is commonly preceded by a failed abortion attempt. This type of offender usually entails an egocentric woman who believes the child would disrupt her chosen lifestyle; thus, she has no sense of responsibility for the child and her attitude towards the newborn child is extremely hostile.

3. In between these two extreme types, there is a third type which is most common in practice. This type of offender is affected by a number of factors, which are mainly reflected in the objective influence of another persons, such as the pressure of a spouse or parent to get rid of the child, working in conjunction with the mental structure of the mother who primarily acts in accordance with the overwhelming sense of dependence in relation to the person she considers important in her life.

On the other hand, on the grounds of different homicidal motives, Resnik (Kecman, Kovačević, 2005: 32) differentiates five types of women who commit neonaticide, depending on the nature of the committed murder at childbirth:

1. Altruistic homicide (usually followed by a suicide or exonerating infliction of pain)

2. Psychotic homicide

3. Unwanted child homicide

4. Involuntary homicide

5. Homicide motivated by revenge on the husband.

\subsection{The criminological profile of a woman who commits neonaticide}

Based on anthropometric measurements, Cesare Lombrozo created a conception of a "born offender"; by examining the structure of human skull and other physical characteristics through autopsy, he concluded that some women are predisposed to commit criminal acts (Ilić, 2016: 132).

\footnotetext{
${ }^{4}$ Konstantinović-Vilić, 1986: 61, cited after Kosewahr, Elfie: Kriterien der Schulddifferenzierung bei Kindestotung, Neue Justiz, pp. 136-138
} 
Biological theories explain the criminality of women through the existence of generative phases in woman's life, under whose impact a woman starts being easily agitated and exhausted. In cases of complex deliveries, there is a likelihood of many short-term and long-term psycho-physical disorders, due to which the mother has no affection for her newborn child and gets estranged from the child.

In the year 1958, Hertzman and Smitz analyzed 45 instances of neonaticide from Tubingen (Germany) and found that the largest number of female offenders ranged from the age of 21 to 25 on average; the next in line were juvenile offenders, while the smallest percentage was recorded in the category of women over the age of 35 .

In the year 1986, Konstantinović-Vilić conducted a research using a sample of 134 women murderers, where she concluded that one third of respondents had a chronic medical condition, such as: rheumatism, low or high blood pressure, diabetes, bronchitis, varicose veins, etc. The same results were reached in the research conducted by Irena Cajner. The results of her research sample showed a tendency towards neurological episodes, such as: scrofulosis, rickets, epilepsy, and psycho-motor insufficiency (Cajner, 1993: 6).

According to the statistics published by the Statistical Office of the Republic of Serbia, in the period from 2011 to 2014, there was a total number of 14 reported neonaticide cases, ten of which were committed by adult offenders and four of them by juvenile offenders. The most frequent punishment was the sentence of imprisonment, while only two offenders were imposed the suspended sentence (Ilić, 2016: 137).

The most extensive research and descriptive analysis of psychological, sociodemographic, financial and socio-cultural characteristics of neonaticide offenders was conducted by Irena Cajner. Using a sample of 30 convicted offenders, she studied the intellectual abilities, personal characteristics, temper, lifestyle, immediate social environment, and family circumstances of women who committed neonaticide (Cajner, 1993:1-13).

The research results showed that $78.9 \%$ of surveyed offenders were women of average intelligence, whose potentials largely remain unused for a number of reasons: they often demonstrate primitive behavior, lack of basic (primary) education, and lack of skills and experience in cases where they had some form of formal instruction. The chosen lifestyle and the rules of the immediate social environment inhibit their intellectual growth, given that a large number of topics are a taboo in such an environment. They often drop out of school early and do menial jobs, without any higher aspirations and with the explicit goal of satisfying the most basic needs. They are impressionable and get involved in sexual relations without a careful choice of partners.

Speaking of their temper, they are commonly solitary and introvert persons, and usually non-aggressive (as neonaticide is often their only criminal act); they are prone to repression, which is frequently reflected in denial of pregnancy and exclusion of distressful thoughts. The prevailing character traits of the neonaticide offenders were: egocentrisms, egoism and primitivism. The research showed that a vast majority of the respondents first focused on satisfying their own needs and only later or retroactively considered the consequences or the impact of such behavior on others. Like everything else, they look at their unborn child through the prism of their own interests and, after perceiving the child as a direct threat to their own wellbeing, they keep repressing the existence of pregnancy, first through its denial and concealment, and then through the act of neonaticide.

Regarding the woman's lifestyle in the nuclear family, there is a notable pattern that women who commit neonaticide often live in isolation and without sufficient social contacts during childhood. They lack the company of their peers, which would be an ideal criterion for 
self-evaluation of their own behavior. In their teens, their relations with boys are further aggravated and significantly reduced due to insecurity, which ultimately results in a lack of experience, naivety and frustrations. The unwanted pregnancy is often the result of their first sexual relations with a man. Cajner's research also showed that their families are strictly patriarchal and conservative, with rigid standpoints on diverse issues and a lot of taboo topics (including sexuality); consequently, there is a prominent fear of the father or both parents. None of the offenders had any doubt about getting rid of the child, which shows their immaturity and reluctance to deal with serious problems encountered in life.

In literature, there are opinions that the criminal offence of neonaticide is commonly committed by single young girls and women. It is worth noting that, in the period before the First World War, there was an equal number of single and married neonaticide offenders, which is explained by economic migrations of men who left their families for longer periods of time. Speaking of married offenders, the research showed the bad quality of their marital relations in $90 \%$ of the cases, while they were good in only $10 \%$ of the examined cases (Cajner, 1993: 11)

Similar results were found in the research conducted by Kecman and Kovačević (Kecman, Kovačević, 2005: 33-36). The research encompassed a sample of 19 women who had committed neonaticide and were forensically treated in the Special Prison Hospital in Belgrade in the period from 1993 to 2002 . The dominant age group of the respondents ranged from the age of 20 to 29 (42.11\%), and 30 to 39 (36.84\%). The majority of respondents only had elementary school education $(42.11 \%)$ and there was a vast majority of unemployed respondents $(84.21 \%)$; the most common occupation was a housewife. Most women in the sample were married; women involved in extramarital relations came second. Interestingly, in $36.84 \%$ of the cases the respondents were brought up in complete and functional families; in $31.58 \%$ of the cases they reported to have been living in dysfunctional families. Their development was marked by different kinds of neurosis. Before the commission of neonaticide, most of them had never visited a psychiatrist and had no prior psychiatric assessment or diagnosis. It is worth noting that none of the respondents had had any delinquent behavior prior to the committed act. They showed no propensity to any addictions; most of them did not consume alcohol and abstained from using drugs. As for their emotions, respondents demonstrated emotional immaturity, instability and impulsiveness. In $50 \%$ of the cases they attempted to commit suicide, whereby seven out of nine attempts occurred after murdering the newborn child.

In 2016, the author of this paper conducted a research on different kinds of homicide committed by women, by exploring the final judicial decisions of the Magistrates (municipality) courts and Higher (county) courts in Niš and Prokuplje. The research sample included cases decided in the period from 1996 to 2016. The findings showed that there were no recorded cases of neonaticide in this sample (Antić, 2016: 64). Yet, it is highly debatable whether these findings are a realistic reflection of the social reality, or rather a result of the fact that the criminal offence of neonaticide largely remains in the grey area of social life, or eventually a consequence of women's emancipation.

\section{CONCLUSION}

Speaking of the current state of affairs, there is a need for both repressive and preventive action aimed at counteracting the commission of neonaticide, especially in rural areas, where it is still present to some extent in spite of the prominent efforts to completely 
eradicate it. The preventive action should involve improved health protection measures, recording and monitoring each pregnancy, suppressing anachronous and patriarchal beliefs regarding extramarital motherhood, further education of future mothers about numerous alternatives as much more efficient solutions than neonaticide. It is also necessary to raise women's awareness of the legislation on this matter and the scope of modern criminological techniques, which would largely discourage them from the commission of this crime as the absolute secrecy of their act would be undermined. Above all, there is a need to improve the position of women in society and promote their independence. Although the battle for emancipation is underway, it has not reached its full potential and intensity in all areas of life.

When viewed from a critical standpoint, the existing criminal legislation is somewhat unsuitable, considering that the act of neonaticide may be considered to be privileged homicide (manslaughter) only if the mother has sustained a post-delivery (mental) disorder cause by childbirth. Yet, there is a justifiable question which could be posed in terms of what happens when the disorder is cause by other circumstances of sociological, psychological or financial nature. Similarly, it is not completely clear why there is a completely different penal policy when it comes to a newborn child as compared to an infant, especially considering the fact that the borderline between a newborn child and an infant is difficult to establish. Should the borderline be precisely determined, there is common agreement that the difference measurable in days is not sufficient justification for a completely different treatment of the mother's act.

Judicial practice shows that the criminal offence of neonaticide has been on the decline, which is also supported by the recent research conducted by the author of this paper. Yet, in light of the presented facts and the frequency of committing this criminal act in the past, neonaticide still deserves significant attention in terms of reconsidering de lege ferenda the criminal legislation on this matter and eliminating disputable provisions and inconsistencies.

\section{REFERENCES}

Antic, Iva. Žene ubice (Female Murderers), neobjavljeni Master rad, Pravni fakultet, Univerzitet u Nišu, 2016 Banerji, Rita, Female genocide in India, In: Intersections: Gender and Sexuality in Asia and the Pacific, Issue 22, October 2009; retrieved from: http://intersections.anu.edu.au/issue22/banerji.htm

Cajner, Irena (1993). Osobne i sociodemografske karakteristike počiniteljica čedomorstva, (Distinctive Features and Socio-demographic Characteristics of the Perpetrators of Neonaticide), Fakultet za defektologiju, Zagreb, 1993.

Craig, Michael (2004), Perinatal risk factors for neonaticide and infant homicide: Can we identify those at risk?, Journal of the Royal Society of Medicine JRSMed 97(2), 2004

Dušanov zakonik (Dushan's Code, 1349); available at http://www.dusanov-zakonik.com/indexe.html

Gendercide Watch, Case Study: Female Infanticide; www.gendercide.org/case_infanticide.html; http://5859d7f0f30e9c1373ac76f52f45edd080d6d6d41139c312cfe3.r43.cf2.rackcdn.com/uploaded/f/0e295 0267_1393615313_femaleinfanticide.pdf

Ilić, Anita (2016). Čedomorstvo (Neonaticide), U: Zbornik radova studenata doktorskih studija prava, Niš, 2016.

Kecman, Ratko; Kovačević, Bojan, Žene ubice svoje dece (Women who kill their own children), Engrami, vol. 27, jul-decembar 2005, br. $3-4$

Konstantinović-Vilić, Slobodanka (1986). Žene ubice (Women who kill), Gradina, Niš, 1986.

Krivični zakonik (Criminal Code of Serbia), "Sl. glasnik RS", br. 85/2005, 88/2005 - ispr., 107/2005 - ispr., 72/2009, 111/2009, 121/2012, 104/2013 i 108/2014)

Šaljić, Eldar (2010), Krivično delo ubistva deteta pri porođaju u Krivičnom zakoniku Srbije (The criminal act of neonaticide in the Criminal Code of Serbia), Univerzitetska misao, Novi Pazar, http://www.academia.edu/ 4887134/KRIVICNO_DJELO_UBISTVA_DJETETA_PRI_PORODAJU_U_KRIVICNOM_ZAKONIKU _SRBIJE

Schwartz, Lita Linzer; Isser, Natalie K, (2012). Endangered Children: Homicide and Other Crimes, $2^{\text {nd }}$ edition, CRC Press, Taylor \& Francis Group, Boca Raton-London-NY, 2012. 


\section{ČEDOMORSTVO}

Ubistvo, kao nesumnjivo najteži i po posledicama najdalekoseženiji akt homo sapiensa, zavređuje enormnu pažnju stručne i opšte javnosti. Međutim, po nekom nepisanom pravilu, uloga ubice obično se pripisuje muškarcu, dok se žena češće posmatra kao žrtva, što ne odgovara u potpunosti društvenoj stvarnosti. Upravo iz tog razloga, ovaj se rad bavi čedomorstvom, kao tipičnim reprezentom ženskog ubistva. Autor rada proučava istorijski, krivični i kriminološki aspect ovog čina u nastojanju da iznađe tipičan profil žene koja vrši čedomorstvo. Međutim, pokazala se istinitom zastrašujuća činjenica da čedomorstvo može izvršiti bilo koja žena, s tim da su neke žene, ipak predisponiranije i sklonije tome. Stoga, autor nastoji da ukaže svojim radom upravo na te karakteristike koje povezuju sve, ili većinu tih žena, izdvajajući ih od ostalih pripadnica istog pola, i, još više, da skrene pažnju (prevashodno stručne) javnosti na ovu atraktivnu, a nedovoljno istraživanu temu sa ciljem njene što potpunije eksploracije u budućnosti.

Ključne reči: čedomorstvo, žena, ubistvo, ubica

Proofreading and translation: Gordana Ignjatović 